\title{
Heideggerowska destrukcja metafizyki: filozofia średniowieczna i nowożyłna. Część I
}

DOI: http://dx.doi.org/10.12775/RF.2014.002

Wysunięte przez Heideggera hasło destrukcji metafizyki trafiło, w moim przypadku, na podatny grunt, gdyż od momentu ukończenia studiów filozoficznych właśnie to zagadnienie interesowało mnie najbardziej. W konsekwencji od lat kompletowałam bibliotekę zawierającą najważniejsze dzieła europejskiej metafizyki. Zewnętrzna krytyka metafizyki, typowa dla neopozytywizmu, zawsze wydawała mi się nietrafiona i powierzchowna, była niejako „drogą na skróty”. Sądziłam, że należy podjać wysiłek wmyślenia się w wielkie koncepcje metafizyki, nie dając im się zarazem uwieść, tak by to przedsięwzięcie wyprowadziło poza metafizykę, przyniosło intelektualną wolność, a zarazem otwarło myśleniu nową perspektywę, odpowiadającą potrzebom dnia dzisiejszego.

Sposób myślenia charakterystyczny obecnie dla trzech wielkich ośrodków filozofii współczesnej: anglosaskiego (logika filozoficzna, filozofia analityczna), niemieckiego (inspiracje pochodzące przede wszystkim od Jürgena Habermasa) oraz francuskiego (postmodernizm) nie ma nic wspólnego - tutaj odwołuję się do ustaleń Martina Heideggera z przezwyciężeniem metafizyki, lecz stanowi skoncentrowaną postać metafizyki nieprzezwyciężonej ${ }^{1}$, do czego mogą dochodzić jakieś epigo-

1 Dobrym wyrazem owego poglądu może być następująca wypowiedź Martina Heideggera: „Wraz z metafizyką Nietzschego filozofia jest w pełni dokonana. Znaczy to tyle, że przebyła już cały krąg swych z góry nakreślonych możliwości. Metafizyka, która dokonała się w pełni, jest podstawą "planetarnego « sposobu myślenia. Tworzy ona rusztowanie dla porządku ziemskiego o znacznej przypuszczalnie trwałości. Ten porządek nie potrzebuje już filozofii, ponieważ ma ją u swych podstaw" (Przezwyciężenie metafizyki, BMM, s. 297). Wykaz skrótów tytułów cytowanych dzieł Heideggera i ich adresy bibliograficzne czytelnik znajdzie na końcu artykułu. 
nalne renesanse, $\mathrm{w}$ rodzaju amalgamatu marksizmu i klasycznej filozofii niemieckiej. Wszędzie, jak sądzę, dominuje skrycie wola mocy. Wspomniane nurty uznaję za jej trzy ideologiczne narodowe ukształtowania.

Przyczynki do filozofii oraz wykłady Nietzsche, zwłaszcza ich drugi tom, utwierdziły mnie w przekonaniu, że Heidegger poszukiwał rozwiązania nurtujących mnie problemów, a z racji wybitnej przenikliwości filozoficznej, erudycji i pracowitości, a także uzyskanego wykształcenia (gimnazjum humanistyczne, dwa lata studiów w kolegium jezuickim, ukończone studia matematyczno-przyrodnicze) był szczególnie predestynowany do uporania się z nimi. W dotychczas opublikowanej książce o Heideggerze ${ }^{2}$ skoncentrowałam się na wykładni podstawowych stanowisk filozoficznych: presokratyków, Platona, Arystotelesa, średniowiecznej scholastyki, Kartezjusza i Immanuela Kanta, idealizmu niemieckiego, Fryderyka Nietzschego na podstawie jego pism późnych. Jedynie tytułem uzupełnienia sięgałam do tekstów napisanych do $1934 \mathrm{r}$. Od kilku lat w Instytucie Filozofii UW prowadzę wykład monograficzny, mający za przedmiot analizę wykładów kursowych Heideggera poświęconych filozofii średniowiecznej i nowożytnej, z uwzględnieniem jego rozprawy habilitacyjnej o Dunsie Szkocie i wykładu habilitacyjnego „Pojęcie czasu w nauce historycznej”. Będąc przekonana, że jest to niezwykle ciekawy materiał badawczy, zdecydowałam się poświęcić mu osobną książkę, nad którą pracuję obecnie. Niniejszy tekst można potraktować jako jej zwiastun i streszczenie.

Wykłady kursowe Heideggera, wydane w Gesamtausgabe (Dziełach zebranych), stanowią ważne, a nawet niezbędne, uzupełnienie książek Heideggera: Bycie i czas, Kant a problem metafizyki, Przyczynki do filozofii, a także wydanych przez niego artykułów. Te ostatnie stanowią jakby „wierzchołek góry lodowej”, ich niewielkim ustępom czy nawet oddzielnym zdaniom odpowiadają $\mathrm{w}$ pismach nieopublikowanych za życia filozofa całe paragrafy, opracowane w sposób systematyczny i poparte gruntownymi studiami. Będę czyniła tutaj użytek z 23, 26 i 28 tomu Gesamtausgabe. Te nieprzełożone na język polski teksty pokazują jak rozbudowane badania stały za często lakonicznymi uwagami odnośnie do poszczególnych koncepcji. Zasada koła hermeneutycznego ma świetne zastosowanie do Heideggerowskiej hermeneutyki.

Tom 23 zawiera wykład Geschichte der Philosophie von Thomas von Aquin bis Kant (Dzieje filozofii od Tomasza z Akwinu do Kanta), wygłoszony w semestrze zimowym 1926/1927, w czasie, gdy Heidegger ostatecznie redagował Bycie i czas. Widoczne są także związki tego wykładu z badaniami, które są treścią książki Podstawowe problemy fenomenologii, zresztą jest to kolejny wykład (semestr letni 1927 r.), opublikowany w 24 tomie

2 E. Borowska, Problem metafizyki. Ewolucja metafizyki europejskiej w interpretacji późnego Heideggera, Wydawnictwo Naukowe SCHOLAR, Warszawa 2008. 
Dzieł zebranych. Tom 23 składa się z tekstu autora, niekiedy w postaci luźnych uwag, a także z wypisów z dzieł omawianych filozofów: Tomasza z Akwinu, Kartezjusza, Barucha Spinozy, Gottfrieda W. Leibniza, Christiana Wolffa, Christiana A. Crusiusa (podrozdział o Kancie ma charakter „domknięcia” wykładu), które często przytaczane są po łacinie. W miarę przystępne przedstawienie treści w języku polskim wymagało dużo pracy, ale opłaciła się ona, ponieważ wiele późniejszych uwag Heideggera o wymienionych filozofach wyraźnie nawiązuje do tutejszych ustaleń.

Pogłębioną interpretację koncepcji Leibniza znajdujemy $\mathrm{w}$ tomie 26 Gesamtausgabe: Metaphysische Anfangsgründe der Logik im Ausgang von Leibniz (Metafizyczne podstawy logiki wychodzac od Leibniza - wykład z semestru letniego 1928 r.). Książka ta stanowi swego rodzaju zapośredniczenie między Byciem i czasem a pracą Kant a problem metafizyki. Rzuca też wiele światła na rozprawę $O$ istocie podstawy (wchodzącą w skład Znaków drogi). Jest starannie przez autora zredagowana.

Tom 28 Gesamtausgabe: Der deutsche Idealismus (Fichte, Schelling, Hegel) und die philosophische Problemlage der Gegenwart (Idealizm niemiecki (Fichte, Schelling, Hegel) i filozoficzna sytuacja problemowa wspótczesności) (wykład z semestru letniego 1929 r.) ma za przedmiot przede wszystkim pierwszą teorię wiedzy Johanna G. Fichtego, a także filozofię wczesnego Fryderyka W. J. Schellinga i wczesnego Georga W. F. Hegla (ponadto kilka cennych uwag o strukturze Fenomenologii i Logiki). Znajdujemy w nim nawiązania do książki Kant a problem metafizyki. W przypadku pracy nad tym wykładem konieczne było drobiazgowe konfrontowanie dość swobodnych notatek Heideggera ze stosownymi dziełami idealistów niemieckich.

Kontynuację analizy filozofii Heglowskiej, której tutaj z braku miejsca nie uwzględnię, zawiera tom 32 Dzieł zebranych: Hegels Phänomenologie des Geistes (Heglowska fenomenologia ducha) (semestr zimowy 1930/1931), gdzie rozważane jest przejście od świadomości do samowiedzy w początkowych paragrafach Fenomenologii ducha. Ten wykład jest z kolei starannie zredagowany przez autora.

Destrukcja metafizyki - czytamy w Byciu i czasie - jest konieczna z tego względu, że uwikłani jesteśmy w pojęcia i konstrukcje filozoficzne uznawane za oczywiste, których pochodzenie uległo zatarciu, a bez właściwego określenia ich „metryki” nie będziemy zdolni do dokonania prawdziwie wolnego wyboru własnej możliwości egzystencji (BC, s. 29-32). W Podstawowych problemach fenomenologii, w związku z zagadnieniem destrukcji, zostały wymienione trzy momenty metody fenomenologicznej. Redukcja fenomenologiczna polega na zwróceniu spojrzenia ku byciu bytu, rozważaniu w perspektywie ontologicznej, nie ontycznej. Konstrukcja oznacza aktywne projektowanie bycia i jego struktur. Fenomenologiczna destrukcja jest natomiast „krytyczną rozbiórką tra- 
dycyjnych i zrazu niezbędnych pojęć docierającą do źródeł, z których zostały one zaczerpnięte" (PPF, s. 25-27). Destrukcja nie jest tutaj zatem niszczeniem, wykazywaniem niedorzeczności, lecz podążającym wiernie za zamysłem autora odsłanianiem sensu badanej teorii, by stworzyć warunki do twórczego sporu. Zasadniczym przedmiotem sporu jest dla Heideggera zagadnienie bycia bytu. Dzięki owemu sporowi mamy uzyskać nowe spojrzenie na dzieje metafizyki.

Destrukcja wyrasta z zasady skończoności ludzkiego jestestwa i ogólniej - dziejowego człowieczeństwa. Stawia sobie zadanie wytyczenia granic teorii filozoficznej, która zwykle mniema, że stoi na stanowisku nieskończoności. Mimo orientacji na skończoność Heideggerowska destrukcja - paradoksalnie - pozwala tradycji przemówić jej własnym głosem, „nie skazuje jej na zmarnienie, lecz właśnie pozytywnie przyswaja ją sobie" (PPF, s. 27). Negatywny sens destrukcji nie dotyczy przeszłości, lecz współczesnej filozoficznej mizerii, kiedy to wykorzeniona tradycja staje się przedmiotem rozlicznych manipulacji $\mathrm{w}$ gadaninie i pisaninie filozoficznej (zob. BC, s. 32) ${ }^{3}$.

Wczesny Heidegger uznaje ludzkie jestestwo, Dasein, za jedność trzech czasowych ekstaz: 1 . „przyszłościowej” ekstazy rozumienia, gdzie każdorazowo bycie bytu rozumiane jest w perspektywie jakiegoś projektu ontologicznego (również projektu własnej egzystencji), obranego przez jestestwo świadomie lub nie w pełni świadomie; 2 odpowiadającej przeszłości ekstazy rzucenia - jestestwo znajduje się w jakiejś sytuacji egzystencjalnej, na którą nie ma wpływu, np. urodziło się $\mathrm{w}$ takich, a nie innych warunkach; rzucenie jest zabarwione emocjonalnie; 3. odpowiadającej teraźniejszości ekstazy upadania, gdzie jestestwo ulega pokusie zbiorowego sposobu bycia bądź się od niego dystansuje, pragnąc być Sobą. Słowo „ekstaza” oznacza, że jestestwo zawsze przekracza siebie i znajduje się na zewnątrz, przy bycie; nie jest jakąś zamkniętą w sobie monadą. Ekstazy nie następują po sobie, ale dane są jednocześnie we wzajemnym związku, np. w każdym momencie życia ustosunkowuję się do własnej śmierci i do własnych narodzin. Tę temporalną interpretację bycia Heidegger przeciwstawia interpretacji bycia po nici przewodniej myślenia typowej dla zachodniej metafizyki.

W analizowanych przeze mnie wczesnych wykładach można odnieść wrażenie, że Heidegger swoją temporalną interpretację bycia w sposób zewnętrzny zestawia z omawianym stanowiskiem: „podsuwa danemu myślicielowi pewne zadanie leżące całkowicie poza jego horyzontem, »dowodząc " później, że go nie rozwiązał" (jest to jego własna uwaga na temat filozofii Kartezjusza, zob. BC, s. 140). Na te sytuacje będę wskazywała. Wydają się one sporym badawczym nadużyciem.

3 Gadanina i pisanina to terminy techniczne Bycia $i$ czasu, oznaczające mowę w modusie niewłaściwości (zob. BC, par. 35). 
Dzieje się jednak coś dziwnego - mimo konfrontacji przeprowadzonej trochę „na siłę", jego spojrzenie jest świeże i odkrywcze. Oferuje jasny wgląd w logikę konstrukcji myślowej i jej związki z innymi. Przejdźmy wszakże do konkretów, które są najciekawsze. Przedmiotem mojego zainteresowania będzie filozofia Tomasza z Akwinu, Kartezjusza, Spinozy, Leibniza, Fichtego, młodego Schellinga i Hegla. Na zakończenie powiem kilka słów o brawurowej interpretacji filozofii Nietzschego, dokonanej jednak tym razem przez późnego Heideggera.

Semestralny wykład, opublikowany jako tom 23 Gesamtausgabe, zawiera unikalne, odosobnione w twórczości Heideggera, 70-stronnicowe studia nad filozofią Tomasza z Akwinu. Zasadniczym punktem odniesienia pozostają tu Kwestie dyskutowane o prawdzie, ale Heidegger uwzględnia też obie Sumy, Kwestie dyskutowane o mocy Boga oraz inne rozprawy św. Tomasza. Uzupełnienie owych studiów znajdziemy w Podstawowych pojęciach fenomenologii (średniowieczne spory o różnicę essentia $i$ existentia) oraz w tomie 26 Gesamtausgabe, poświeconym Leibnizowi. Skupię się tu jedynie na obu nieprzełożonych na język polski tomach Dziet zebranych.

Heidegger podkreśla przełomową rolę średniowiecznej scholastyki: "fundamentalne problemy Ja oraz całą nowożytną filozofię można zrozumieć tylko z perspektywy średniowiecza, a konkretnie z perspektywy jego ogólnej teorii bycia (ontologii)". Praca filozoficzna św. Tomasza dokonała się na gruncie teologii i w jej służbie, nastąpiła tutaj „recepcja arystotelesowskiej filozofii w system wiary [chrześcijańskiej - E. B.]" (GA 23, s. 1-2, 44). Nowożytny ideał poznania zorientowany jest na boską wiedzę w scholastycznym ujęciu:

Prawda źródłowa, tzn. całość wszelkiego prawdziwego poznania, jest absolutnie, mianowicie w scientia Dei [wszystek byt jest prawda, tzn. poznawany jest przez boski intelekt - E. B.]. [...] Bez znajomości i zrozumienia tych związków podstawowe problemy nowej filozofii pozostają całkowicie niedostępne. Scholastyczna teoria Boga jest nie tylko kluczem do logiki Leibniza, także Krytyka czystego rozumu Kanta i Logika Hegla są tylko wychodząc stąd zrozumiałe w swych właściwych tendencjach. Nie chcę przez to powiedzieć, że ta filozofia wzoruje się na teologii i od niej zapożyczyła swe twierdzenia. Filozoficzny sens orientacji na scientia Dei jest następujący: funkcjonuje ona jako konstrukcja absolutnego poznania, którym powinno być mierzone skończone ludzkie poznanie (GA 26, s. 54).

Ontologiczną propedeutyką teologii można nazwać okazanie pojęć transcendentalnych w Kwestiach dyskutowanych o prawdzie (kwestia I). Jest to jawny, aczkolwiek szczątkowy wywód ontologiczny Tomasza, u którego wszystko jest podporządkowane teologii. Pojęcia transcendentalne rzeczy, jednego, czegoś, prawdy i dobra są zamienne z pojęciem bytu. 
Nie można przeprowadzić ich ścisłej logicznej dedukcji (demonstrari) z centralnego pojęcia bytu, a tylko okazać, ujawnić (manifestari) ich zamienność na byt i na pozostałe transcendentalia. Heidegger porównuje umiejscowienie transcendentaliów względem siebie z Kwestii dyskutowanych o prawdzie i z dziełka De natura generis. Święty Tomasz rozważa tam wzajemne związki pojęć transcendentalnych (gdzie indziej tylko je wymienia), przy czym oba ujęcia nieco się różnią (GA 23, s. 48-55, 214-218). Echo tych rozważań można odnaleźć w Byciu i czasie (BC, s. 21).

Najwięcej miejsca Heidegger poświęca pojęciu prawdy, za którym skrywa się dobrze opracowana, rozbudowana teoria poznania Akwinaty. Pojęcia transcendentalne prawdy i dobra oznaczają rozważanie bytu w odniesieniu do ludzkiej duszy: odpowiedniość bytu względem władzy poznawczej duszy (intelektu) wyraża pojecie prawdy, względem władzy pożądawczej duszy (woli) - pojęcie dobra4 ${ }^{4}$. Faktycznie jednak Tomasz sprowadza wszelki byt stworzony do bytu absolutnego - Boga. Stworzenie jest tym, co przez Boga pomyślane i pożądane (tzn. co od niego wychodzi i z powrotem do niego dąży) (GA 23, s. 98).

Fundamentalnym założeniem scholastycznej teorii poznania jest przyjęcie dwóch aktywności ludzkiego intelektu: 1 . formowania istoty przez oddzielony od zmysłowości intelekt myślący intuicyjnie (simplex apprehensio) oraz 2. myślenia dyskursywnego powiązanego ze zmysłowościa, polegającego na składaniu i rozdzielaniu pojęć. Chodzi tu o jedną władzę ludzkiej duszy. Myślenie dyskursywne (rozumowanie) ma się tak do aktu intelektu formującego istoty, jak ruch do spoczynku. Ruch myślenia przebiega od spoczynku do spoczynku: proste ujęcie istoty - rozumowanie - sformułowanie miarodajnej definicji ${ }^{5}$. Bóg oraz anioły myślą wyłącznie intuicyjnie, choć mają znajomość myślenia dyskursywnego. Bóg, poznając zasadę, widzi od razu wszystkie wynikające z niej wnioski; uchwytując istotę czegoś, widzi wszystko, co można

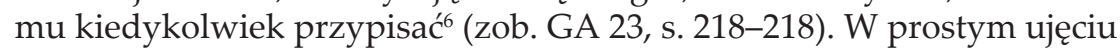
istoty jesteśmy bezpośrednio oświeceni przez Boga. To scholastyczny substytut nieskrytości bycia - jak już wspomniałam, podług Heideggera bycie bytu jawi się zawsze w horyzoncie projektu ontologicznego, determinującego sposób rozumienia bycia, tak więc bycie jest zawsze jakoś rozumiane, otwarte, odkryte (GA 23, s. 59, 60).

Właściwa prawda ludzkiego intelektu w sensie klasycznej definicji prawdy (zwanej dalej adekwacją): adaequatio rei et intellectus, dosłownie: odpowiedniości, zrównania intelektu i rzeczy, dotyczy myślenia dyskursywnego. W simplex apprehensio intelekt zachowuje się czysto odbiorczo.

4 Św. Tomasz z Akwinu, Kwestie dyskutowane o prawdzie, kw.1, art.1.

5 Idem, Suma teologiczna, cz. 1, kw. 79, art. 8; kw. 85, art. 5; idem, Kwestie dyskutowane, kw. 1, art. 3.

6 Idem, Suma teologiczna, cz. 1, kw. 58, art. 4. 
Prawda wyczerpuje się tu w samym tylko byciu danym. Prawda jako adekwacja, mówiąc ściśle, oznacza nie tyle zrównanie intelektu i rzeczy, co zgodność sądu ze stanem rzeczy, stwierdzonym przez ten sąd. Wówczas intelekt ma coś własnego, co nie znajduje się w rzeczy: to, co poznane, jest w poznającym na sposób poznającego ${ }^{7}$. Jeśli stwierdzam: „Tablica nie jest czerwona", to w rzeczywistej tablicy nie ma ani pojęcia „nie”, ani pojęcia „czerwieni” (GA 23, s. 58, 62). W związku z zagadnieniem adekwacji pojawia się u św. Tomasza ciekawa konstrukcja reditio in se ipsum (powracania do siebie). Heidegger sygnalizuje w omawianym wykładzie, że ma ona zastosowanie także w filozofii Kartezjusza i Leibniza (zob. GA 23, s. 80-81, 121, 179-180) ${ }^{8}$. Rozważając poznanie zmysłowe, św. Tomasz zauważa, że zmysł zachowuje się względem rzeczy tak jak intelekt, a względem intelektu, tak jak rzecz. Ogień coś ociepla, ale nie wie o tym, że to czyni. Zmysł, poznając, wie o tym, że poznaje, ale nie wie jak - aktowi ludzkiego poznania zmysłowego towarzyszy świadomość, że ów akt zachodzi, ale natura aktu nie jest znana. Poznający intelekt z kolei nie tylko wie o tym, że poznaje, ale wie, jak poznaje - zrównując się z rzeczą mianowicie. Bezcielesne substancje intelektualne (Bóg i anioły) poznają własne poznawanie i tym samym powracają do swej istoty. Im głębsze poznanie i powrót do siebie, tym większa możliwość wyjścia poza siebie. Bóg posiada doskonałą samowiedzę i jest zdolny do najdalszego wyjścia poza siebie - do stworzenia świata (GA 23, s. 220)9.

Rozważając pytanie, czy zmysły mogą łudzić, Tomasz dochodzi do wniosku, że zmysły nie wprowadzają człowieka w błąd, gdyż zawsze prawdziwie informują intelekt o swym stanie. Także intelekt nie jest ostatecznie źródłem błędu, ale wyobraźnia: widząc żółty świecący metal, zbyt pospiesznie, nie wykonując właściwych analiz, wyrokujemy, że jest to złoto; wyobraźnia podsuwa pewne pojęcie, kierując się tym, do czego przywykliśmy (GA 23, s. 81-82) ${ }^{10}$. Wątek wyobraźni jako władzy poznawczej pośredniczącej między zmysłowością i intelektem będzie obecny - jak zobaczymy - u Kartezjusza, Spinozy, Leibniza, a zwłaszcza u Kanta i w idealizmie niemieckim.

Modelowym poznaniem prawdziwym jest boska wiedza. Tę św. Tomasz dzieli na konieczną wiedzę naturalną, zwaną też wiedzą prostego rozumienia, oraz wiedzę wolną zwaną wiedzą oglądu. Pierwsza dotyczy czystych możliwości, idei rzeczy, bez względu na to, czy zostały one urzeczywistnione w stworzeniu, czy też nie. Granicznym warunkiem

7 Zob. idem, Kwestie dyskutowane, kw. 1, art. 1, 2 i 3.

8 Można ją odnaleźć także u Barucha Spinozy, choć Heidegger tego bezpośrednio nie stwierdza, zob. dalej.

9 Zob. idem, Kwestie dyskutowane, kw. 1, art. 9; idem, Suma teologiczna cz. 1, kw. 14, art. 3.

10 Idem, Kwestie dyskutowane, kw. 1, art. 10 i 11. 
jest tu niesprzeczność logiczna. Druga dotyczy tego, co jest, było i będzie. Jest to możliwość zdeterminowana niejako do istnienia. Odnoszą się do niej sądy egzystencjalne. Bóg posiada oba rodzaje wiedzy: rozważa czyste możliwości i widzi jednocześnie to, co przeszłe, przyszłe i teraźniejsze, jakby z wysokiej góry oglądał drogę biegnącą doliną. Bóg poznaje istotę i istnienie wszystkich bytów nie drogą wnioskowania, lecz „za jednym zamachem”. Na tej podstawie Leibniz dokona później zrównania prawd koniecznych i przypadkowych, sprowadzając obie do pierwotnych zdań tożsamościowych (GA 26, s. 55-59) ${ }^{11}$.

W przypadku pojęcia transcendentalnego dobra byt zostaje odniesiony do woli, w punkcie wyjścia do woli ludzkiej, ale de facto do woli boskiej. Każdy byt stworzony jest pożądany przez Boga i zwrotnie dąży do niego w specyficzny dla siebie sposób. Tomasz odróżnia dążenie naturalne (appetitus naturalis) od dążenia rozumnego (appetitus rationalis). Dążenie rozumne, tj. wola, samo siebie prowadzi ku celowi. Dążenie naturalne zostaje niejako zawleczone do celu, tak jak zmierza do celu strzała wystrzelona przez łucznika (GA 23, s. 99) ${ }^{12}$. Ontologicznie patrząc - zauważa Heidegger - dobro ma to samo źródło, co byt. Jest nim wytwarzanie przez Boga. Poszczególny byt stanowi rezultat boskiej produkcji (GA 23, s. 97).

Przy tej okazji Heidegger zamieszcza kilka uwag na temat specyfiki ludzkiego działania celowego. Odniesienie do celu jest pewną strukturą ontologiczna, przynależną ludzkiemu jestestwu. Cel jako taki ma charakter konieczny, przypadkowo wyznaczony jest tylko cel określony (cel w sensie ontycznym) lub jego brak - bezcelowość. Łatwo wskazać podobne struktury ontologiczne, mające charakter kierowania się na coś: oczekiwanie, obawianie się, kochanie itp. Na przykład brak oczekiwań wymaga istnienia możliwości oczekiwania czegoś w ogóle (GA 23, s. 100, 223).

Zgodnie z tradycją antyczną i wbrew szkole augustyńsko-franciszkańskiej Tomasz zajmuje stanowisko intelektualistyczne (a nie woluntarystyczne). Uważa, że poznanie Boga jest ważniejsze niż dążenie do niego (nawet w postaci miłości), choć ów priorytet poznania obowiązuje dopiero w życiu pozagrobowym (w życiu doczesnym, gdy człowiekowi dostępne jest tylko niedoskonałe poznanie istoty Boga, miłość do Boga ma pierwszeństwo). Poznanie Boga jako pierwszej przyczyny wszechrzeczy stanowi ostateczne zaspokojenie ludzkiego intelektu. Towarzyszy mu uczucie rozkoszy. Oba elementy składają się na wizję uszczęśliwiającą (zob. GA 23, s. 224-225) ${ }^{13}$.

11 Idem, Suma teologiczna cz. 1, kw. 14, art. 9, 13, 14.

2 Ibidem, cz. 1-2, kw. 1, art. 1 i 2.

13 Ibidem, cz. 1-2, kw. 3, art. 2, 4, 8; kw. 4, art. 2, 3. 
Analiza pojęć transcendentalnych miała, jak powiedziano, charakter propedeutyczny. Natomiast kluczem do ontologii św. Tomasza sa, w opinii Heideggera, jego tzw. dowody na istnienie Boga ${ }^{14}$. Dowody te stanowia, co prawda, wywód ontyczny, nie ontologiczny, gdyż dotyczą konkretnego bytu - bytu najwyższego. Łatwo wszakże zrekonstruować horyzont rozumienia bycia, leżący $\mathrm{u}$ ich podstaw. Jest to rozumienie bycia w horyzoncie pracy, wytwarzania. Dominująca perspektywą jest „wytwarzanie i to, co wytworzone, jako obecne” (GA 23, s. 94). Bóg staje się tu "producentem”, wytwórcą rzeczywistości; to, że tworzy on z niczego, w żaden sposób nie obala tej tezy, lecz raczej ją potwierdza. Staje się bowiem producentem doskonałym, znającym swój wytwór lepiej niż człowiek. Materia podlegająca formowaniu jest również jego dziełem (GA 23, s. 94) ${ }^{15}$. Potoczne rozumienie bycia z perspektywy techne (tzn. poręczność bytu, jego charakter narzędziowy, wyłaniający się z uniwersalnej struktury ontologicznej bycia-w-świecie) zostało tu uogólnione na każdy byt (GA 23, s. 95). Heidegger wskazuje także (zob. GA 23, s. 91, 222) na uzasadnienie istnienia Boga przez Tomasza sposobem „ponieważ" (rozumowanie quia), tzn. posuwając się od skutków do przyczyny - przeciwstawny sposób rozumowania zastosuje Spinoza (propter quid, "dlaczego").

Osobny paragraf (GA 23, s. 85-89) Heidegger poświęca scholastycznej teorii analogii bytu (analogiczności bycia). To temat pojawiający się także w habilitacyjnej rozprawie o Dunsie Szkocie (GA 1, s. 255-258) oraz w Byciu i czasie (BC, s. 133). W uzupełnieniu do wykładu o Schellingu z 1941 r. Heidegger porównuje scholastyczną teorię analogii z Heglowską dialektyką. Skok ku prawdzie Bycia (jako wydarzania) ma zapewnić przezwyciężenie zarówno jednej, jak drugiej (RS, s. 294-296; GA 49, s. 187-191).

Jako że opracowanie wykładu Geschichte der Philosophie zbiegło się z ostatecznym redagowaniem Bycia $i$ czasu, nie dziwi rozbudowana analiza teorii czasu przedłożonej przez Akwinatę i nawiązującej do Arystotelesa, a także fenomenów pokrewnych: wieczności - aeternitas, wiecznotrwałości - sempiternitas (chodzi tu o bezkresny upływ czasu w postaci „rzeki” lub „koła”, trwanie tego, co przemijające) oraz wiekuistości - aevum (czasowość aniołów). Wieczność to miara istnienia całkowicie stałego, niezmiennego. Pojęcie wieczności jako nunc stans, „teraz stojącego", zostało uzyskane drogą zaprzeczenia z pojęcia czasu jako nunc fluens, ",teraz upływającego"; usunięto po prostu wszelki ruch, zmienność "teraz". Nie jest istotne, że wieczność nie ma początku i końca, gdyż sempiternitas też jest ich pozbawiona, ale „teraz” jest tu „jedno

14 Nie są to dowody w sensie ścisłym, a jedynie racje uzasadniające istnienie jedynego wyróżnionego bytu, którego istota polega na istnieniu właśnie.

15 Zob. też ibidem, cz. 1, kw. 14, art. 8 i 11. 
po drugim", czyli znajduje się niejako w ruchu. Pośredni fenomen między czasem i wiecznością - aevum - stanowi miarę istnienia niezupełnie stałego. Istnienie tych bytów nie podlega zmianie, ale są one zmienne co do wyboru, poznania, uczuć i miejsc. Tomasz wyraźnie uznaje za rzecz drugorzędna, że anioły mają początek i nie mają końca (GA 23, s. 73-79) ${ }^{16}$.

Podążając za Tomaszem, Heidegger rozważa definicję Boecjusza: wieczność jest całym naraz ${ }^{17}$ posiadaniem bezkresnego życia ${ }^{18}$. Uwagę filozofa fryburskiego przykuwa słowo „posiadanie” (possesio), czyli „posiadłość", ,"mienie” (Besitz) (GA 23, s. 75-76). Jest to potoczny sens słowa ousia w języku greckim. Skoro interpretacja czasu odwołuje się do ruchu, a nawet sam czas jest jakimś wyróżnionym, źródłowym ruchem, to rodzi się pokusa, by identyfikować go z jakimś ruchem we wszechświecie. Zachodzi to u Platona, Arystotelesa i Tomasza z Akwinu - czasem jest dla nich obrót nieba gwiaździstego. Pogląd ów wyrasta z przekonania, że w czasie jest jedynie to, co ma charakter cielesny. Tomasz świadomie pomija popularną w XIII w. subiektywistyczną teorię czasu z księgi XI Wyznań św. Augustyna. Czyni to ze względów teologicznych: duchowa część ludzkiej duszy ma być wiekuista i autonomiczna; miłość, radość, akty woli oraz czyste poznanie rozgrywają się poza czasem. Stany fizjologiczne ciała oraz wszystkie ich pochodne przebiegają w czasie (GA 23, s. 72-73).

Heideggerowska destrukcja metafizyki Tomasza z Akwinu polega na nieco zewnętrznym - jak już wspomniano - konfrontowaniu ustaleń ontologii fundamentalnej z rozwiązaniami Akwinaty. Odnośnie do pojmowania prawdy jako adekwacji Heidegger wysuwa zarzut, że Tomasz nie wchodzi bliżej $\mathrm{w}$ relację między byciem i poznaniem i nie zastanawia się, czy „zgodność" właściwie tę relację wyraża (GA 23, s. 63). Adekwacja zakłada uprzednią otwartość, odkrytość bycia, tę scholastyczna teoria poznania identyfikuje z prostym ujęciem istoty, simplex apprehensio. To, że byt w ogóle jest otwarty, dostępny dla poznania, stanowi dla Heideggera ontologicznie słuszny punkt wyjścia. Tomasz idzie w kierunku realnego stosunku zgodności poznania z bytem, a nie stosunku intencjonalnego, przyjętego później przez Dunsa Szkota (zob. GA 23, s. 99, przypis). Ten drugi bliższy jest Heideggerowskiej koncepcji transcendencji Dasein (trancendencja jako ontologiczna podstawa dla ontycznej intencjonalności - zob. PPF, s. 222-224; GA 26, s. 160-171).

O rozumieniu bycia przez jestestwo w wolnym, "rzuconym” projekcie $w$ ramach średniowiecznej scholastyki oczywiście nie może być mowy. Wprawdzie „,to, co poznane, jest w poznającym na sposób pozna-

16 Ibidem, cz. 1, kw. 10, art. 2, 4, 5.

17 „Całe naraz" jako przeciwieństwo ,jednego po drugim”.

18 Św. Tomasz z Akwinu, Suma teologiczna, cz. 1, kw. 10, art.1. 
jącego" ${ }^{\prime 19}$, ale specyficzne bycie człowieka jako istoty poznającej nie podlega u Tomasza analizie. Umyka zasadnicza ontologiczna odmienność jestestwa względem rzeczy (tzn. bytów obecnych) (GA 23, s. 63).

Kolejny tradycyjny zarzut Heideggera to prymat stałej obecności i oceny ludzkiej egzystencji z tego punktu widzenia. Dla Tomasza ideałem pozostaje nieprzerwana wieczna czynność ludzkiego intelektu przebywającego po śmierci ciała w Bogu w wizji uszczęśliwiającej (GA 23, s. 102, 224-225) ${ }^{20}$.

Najwyższym sposobem bycia człowieka, tzn. jego właściwym byciem, jest takie zachowanie, że [dochodzi się] do aei, do tego, co absolutnie obecne, trzymając się go i zanikając w nim, [uzyskuje się] spoczynek, diagoge. Odpowiada on absolutnej niewypaczoności absolutnego bytu. Idea ludzkiej egzystencji to czysta współczesność uwspółcześniania, które jest dobrem najwyższym (GA 23, s. 103).

Ten sam prymat czystej obecności i współczesności jako wyróżnionej dziedziny czasu odnajduje Heidegger u Kartezjusza, Kanta i Hegla ${ }^{21}$. U tego ostatniego idea absolutna stanowi jedność oglądu i dialektycznej refleksji (GA 23, s. 103).

Dla porządku należy wreszcie przypomnieć tezę Heideggera, że pojmowanie przez Akwinatę Boga jako absolutnego wytwórcy, znającego doskonale każdy powołany do istnienia byt jednostkowy, sprowadza się $\mathrm{w}$ istocie do projekcji poręczności bytu na całą rzeczywistość.

Kolejny temat rozpatrywany w Geschichte der Philosophie to Medytacje o pierwszej filozofii Kartezjusza. Wprawdzie Heidegger później często będzie się zajmował filozofią Kartezjusza, odwołując się do Medytacji, jednak nigdy nie będzie tego czynił równie systematycznie jak tutaj. W Byciu i czasie wiele miejsca poświęcono res extensa, kojarzonej z Kartezjańskim pojęciem świata (zob. BC, par. 19), część druga książki natomiast, gdzie miała zostać przebadana res cogitans w jej związkach ze scholastyczną ontologią oraz poddany destrukcji ontologiczny fundament cogito ergo sum (zob. BC, s. 56), nie doczekała się publikacji. Tymczasem passus o Kartezjuszu w Geschichte pozwala z dużym prawdopodobieństwem zrekonstruować ów brakujący fragment Bycia $i$ czasu (z kolei w Geschichte Heidegger wyraża gotowość rozważenia res extensa w związku z pojęciem świata u Kartezjusza, ale ostatecznie czyni to w sposób marginalny - zob. GA 23, s. 137).

Neokantyści przed I wojną światową lansowali tezę (pokutującą niekiedy do dzisiaj), że Kartezjusz przyszedł znikąd i rozjaśnił ciemności

19 Zob. przyp. 7.

20 Zob. św. Tomasz z Akwinu, Suma teologiczna cz. 1-2, kw. 3, art. 2.

21 Dotyczy to też oczywiście Spinozy i Gottfrieda W. Leibniza. 
średniowiecza. Wprost przeciwnie - stwierdza Heidegger - dowodzi to tylko ignorancji neokantystów, którzy nie zdawali sobie sprawy, jak bardzo przesiąkł on w La Fleché jezuicką scholastyką, choćby ze względu na bardzo intensywny, trzyletni kurs filozofii. Kartezjusz nie tylko stosował scholastyczną terminologię, lecz także bezkrytycznie przejął ówczesne konstrukcje ontologiczne, np. podział na Boga i stworzenie (dzielące się dalej na substancję myślącą i rozciągłą) (GA 23, s. 105, 108-109). Jednakże, obok wpływu Tomasza z Akwinu i jezuitów: Franciszka Suareza i Eustachiusza a Santo Paulo, trzeba koniecznie uwzględnić - podług Heideggera - wpływ oratorian; Kartezjusz znał osobiście kilku wybitnych przedstawicieli tej kongregacji księży, na czele z ich przywódca, kardynałem Pierre'em de Bérulle'em . Odwoływali się oni przede wszystkim do św. Augustyna, św. Pawła i św. Bernarda z Clairvaux. W środowisku tym żywo dyskutowano kwestię ludzkiej wolności w konfrontacji z boską łaską. Ówczesna faza starego sporu zapoczątkowana została przez wystąpienie Martina Lutra (De servo arbitrio, 1525 r.), a następnie kontrofensywę kardynała Roberta Bellarmina na Soborze Trydenckim. Czwarta medytacja, centralna $\mathrm{w}$ opinii Heideggera, porusza problem wolności ludzkiej woli (zob. GA 23, s. 109-112).

Ponadto René Descartes był niewątpliwie zainspirowany postępami fizyki matematycznej, która szukała specyficznej prawodawczości przyrody, wolnej od nadprzyrodzonej ingerencji; w związku z tym ideałem poznania stawała się metoda matematyki. Dodatkowo renesansowy humanizm pozostawiał człowiekowi swobodę samorealizacji. $\mathrm{W}$ rezultacie, mimo przejęcia dotychczasowego projektu ontologicznego i postaci nieskrytości: wytwarzania bytu przez Boga, Kartezjusz modyfikuje pojęcie prawdy sądu - to pewność, obowiązywanie; na czoło wysuwa się ludzki podmiot poznający, a bycie przyrody zostało skonstruowane na matematyczną modłę (dwa ostatnie momenty - dodajmy - to Kartezjański odpowiednik Dasein i bycia-w-świecie) (GA 23, s. $110-111,105)$.

Dalej zreferuję najważniejsze uwagi Heideggera do poszczególnych medytacji. W Medytacji I Descartes pyta o nowy, pewny fundament poznania. Heidegger dodaje, że ma on przybrać postać zdania oznajmującego i że ideał ścisłego poznania jest już z góry dany, bez przeprowadzenia należytej dyskusji (GA 23, s. 113). Kartezjusz metodycznie bada kolejno wyłaniające się sposoby poznania i wyraża swe wątpliwości: świadectwo zmysłów, szaleństwo i sen, wyobraźnia, pojmowanie intelektualne, czyste pojmowanie intelektualne dotyczące najbardziej ogólnych przedmiotów nauk matematycznych. W ostatnim przypadku w grę wchodzi tylko zarzut możliwej ingerencji boga-zwodziciela. Heidegger pyta, dlaczego tego istotnego zbłądzenia człowieka Kartezjusz nie rozważył na początku. Po co przebadał wcześniej wszystkie władze poznawcze? Odpowiedź brzmi, że poszukiwany fundament poznania 
ma także zabezpieczyć poznanie Boga, które ze swej strony zagwarantuje, że moje poznanie nie jest z góry spaczone (GA 23, s. 114-116).

W Medytacji II zostało wypowiedziane sakramentalne „Myślę, więc jestem". Nie jest to implikacja, gdyż mogę nie istnieć. Nie jest to też jakiś ogląd tego, co dane. Zdanie to mówi tylko, że moje bycie jest współdane tak długo, jak długo myślę, i odwrotnie; jest to pewne absolutnie jako prawda wrodzona (GA 23, s. 117-118). Aby określić istotę Ja, Descartes czyni użytek z dotychczasowej drogi wątpienia. Jestem myśleniem (cogitare). Poznanie zmysłowe i wyobrażanie sobie mogą być ułuda, ale przecież są ukonstytuowane przez samowiedzę. Ma tu miejsce powracanie władzy poznawczej do siebie ${ }^{22}$. Intelekt postrzega siebie na swój własny sposób. Im doskonalsza władza poznawcza, tym bardziej źródłowy jej powrót do siebie. Rzeczy cielesne, takie jak wosk, ujmuję zasadniczo umysłem. Poznanie umysłowe wyznacza dopiero nieskończone możliwości zmian owych rzeczy, które mogę sobie wyobrazić (GA 23, s. 119-122).

Na początku Medytacji III Kartezjusz expressis verbis formułuje stosowane przez siebie kryterium prawdy, nazywane zasadą ogólną (regula generalis): prawdziwe jest to, co jest jasne i wyraźne. Nowe twierdzenia teorii metafizycznej mogą być dołączone do dotychczasowych tylko na mocy tej zasady ${ }^{23}$. Jednakże „o ile istnienie Boga nie jest absolutnie ustalone oraz [nie jest ustalone] przez to, że nie jest on zwodzicielem, zasada ogólna nie jest zabezpieczona" (GA 23, s. 124)24. Kartezjusz zmierza do tego, by dowodząc istnienia Boga, mógł udowodnić także istnienie rzeczy poza Ja. Wyłania się tu problem pierwotnej transcendencji ludzkiego jestestwa, tak ważny dla młodego Heideggera. Descartes dzieli idee na wrodzone i nabyte. Te drugie mają rzekomo pochodzić od rzeczy transcendentnych wobec Ja. Poucza o tym popęd naturalny: towarzyszące im uczucie przyjemności lub przykrości oraz ich niezależność od ludzkiej woli. Jednak transcendowanie nie jest ugruntowane $\mathrm{w}$ sensie zasady ogólnej, nie jest absolutnie pewne (GA 23, s. 126).

Dalej, jak wiadomo, Kartezjusz rozważa rzekomo wrodzoną ideę aktualnej nieskończoności wszystkich doskonałości, będącą ideą Boga. Ma ona posiadać przymiot jasności i wyraźności ${ }^{25}$. Powołując się na scholastyczną dystynkcję rzeczywistości obiektywnej (realitas objectiva) idei - chodzi o treść pojęcia istniejącą tylko w myśli - oraz jej rzeczy-

22 Zob. wcześniej.

${ }^{23}$ Zob. R. Descartes, Medytacje o pierwszej filozofii wraz z zarzutami uczonych mężów i odpowiedziami autora, t. 1, przeł. M. i K. Ajdukiewiczowie, PWN, Warszawa 1958, s. 52-53, 68-69, 87.

${ }^{24}$ Heidegger przypomina w tym miejscu stawiany Kartezjuszowi zarzut błędnego koła.

25 Zob. ibidem, s. 60, 62, 68. 
wistość formalną lub aktualną (realitas formalis, actualis) - to rzeczywistość bytu, któremu idea odpowiada - francuski filozof dowodzi, że rzeczywistość obiektywna idei Boga przewyższa rzeczywistość aktualną ludzkiego Ja, a zatem nie mogło ono być jej przyczyną. Przyczyną owej idei może być tylko nieskończenie doskonały Bóg. Wątpliwości budzi zrównanie poziomów myślenia i rzeczywistości (rzeczywistość logiczna stanowi np. dla Dunsa Szkota byt zredukowany, ens diminutum, którego nie można utożsamiać z bytem realnym; wszystko jest tu jak gdyby w jednym rodzaju, podczas gdy świat zmysłowy dzieli się na różnorakie gatunki i rodzaje). Heidegger podkreśla inny aspekt argumentacji Descartesa: cały wywód dowodzi bezkrytycznego zastosowania zasady powszechnej przyczynowości, przejętej ze scholastyki (GA 23, s. 129).

W Medytacji IV Kartezjusz chce zrozumieć, jak doskonały Bóg mógł pozwolić, by człowiek podlegał rozlicznym błędom. Czy lepiej, bym się mylił, czy też, żebym się nie mylił? ${ }^{26}$ Ludzkie błędne poznanie - odpowiada - wynika ze współdziałania intelektu i woli. Wola w sposób nieuprawniony uznaje za prawdziwe poznanie, które nie jest jasne i wyraźne. Rozpiętość ludzkiej woli przewyższa rozpiętość intelektu, jest nieskończona - jak u Boga; świadczy to o tym, że człowiek został stworzony na jego obraz i podobieństwo. Ściślej rzecz biorąc, chodzi tu tylko o nieobecność determinacji woli, jej bezstronność, brak przymusu. Niezdecydowanie przy wyborze jest bowiem - zastrzega Kartezjusz najniższym stopniem wolności. Im bardziej dążę do dobra, tym bardziej jestem wolny. Łaska boska i poznanie nie umniejszają wolności, lecz ją wzmagają ${ }^{27}$. Heidegger odnajduje tu Augustyńską zasadę propensio in bonum, upodobania $\mathrm{w}$ dobru: człowiek z natury dąży do dobra i szczęścia, choć może je błędnie rozpoznawać (GA 23, s. 132).

Medytacje $V$ rozpoczyna analiza tego, co można wyraźnie poznać w rzeczach zewnętrznych wobec Ja. Spełniają ten warunek aspekty rozciągłości: wielkość, kształt, ruch, liczba. Wiedza o stosunkach geometrycznych jest wrodzona. Stanowi to wstęp do kolejnego dowodu istnienia Boga - dowodu ontologicznego. Pojęcie Boga jest tak powiązane z jego istnieniem, jak z pojęcia trójkąta wynika, że suma kątów wynosi 180 stopni. Ów związek występuje nie dlatego, że narzuca to konieczność mojej myśli, ale odwrotnie: konieczność samej rzeczy zmusza mnie do takiego myślenia (GA 23, s. 135) ${ }^{28}$.

Dopiero w Medytacji VI Kartezjusz opuszcza sferę immanencji i rozważa możliwość istnienia rzeczy materialnej, transcendentnej względem świadomości. To, co w rzeczy materialnej jest przedmiotem

\footnotetext{
26 Ibidem, s. 73.

27 Ibidem, s. 76-77.

28 Zob. ibidem, s. 85, 88-89.
} 
czystej matematyki, może istnieć naprawdę. Heidegger wskazuje, że zabezpiecza to możliwość rzeczy materialnej, ale nie jej rzeczywistość (GA 23, s. 135). W celu wykazania istnienia res extensa Descartes przywołuje władzę wyobraźni. Wyobraźnia jest szczególnym wysiłkiem ducha. Wykazuje to następujący eksperyment: mogę pojąć trójkąt intelektem i wyobrazić go sobie. Mogę także pojąć intelektem tysiącokąt, ale wyobrazić go sobie jako takiego nie mogę, niejasno unaoczniony tysiącokąt nie różni się w niczym od dziesięciotysiącokąta ${ }^{29}$. Ludzkie Ja jest myśleniem i działaniem. To, co mogę sobie wyobrazić, najpierw jest w zmyśle i pamięci. Wyobraźnia jest więc zależna od jakiejś rzeczy zewnętrznej wobec Ja ${ }^{30}$. Wszelako dowód ten „nie ma tego stopnia pewności, co stosowane dotychczas dowody na istnienie Boga, nie można w równie pewny sposób dowieść, że świat, moje ciało istnieją" (GA 23, s. 137).

W omawianym obecnie wykładzie Heidegger wyczerpująco przeprowadza destrukcję Kartezjańskiej res cogitans (zob. GA 23, s. 138-139). Wprawdzie Kartezjusz, przyjmując zdecydowaną orientację na podmiot myślący, daje filozofii nowożytnej nowy początek i założenie, ale nie przeprowadza właściwej ontologicznej charakterystyki owego podmiotu; nie pyta o bycie i nie bada relacji między prawdą a byciem. Prawda jest dla niego pewnością uniwersalnie obowiązującą (przy czym stawia znak równości między prawdą i jej uznaniem - przyjmuje woluntarystyczną teorię sądu). W ogóle nie pojawia się tu możliwość, by prawda jako nieskrytość dopasowana była do sposobu bycia rozważanego bytu. Powodem tego zaniechania jest zasadnicza orientacja na pewność poznania. Ekstremalne sformułowanie tej tezy mogłoby, według Heideggera, brzmieć: tak naprawdę jest przypadkiem, że fundamentalna prawda dotyczy ego i cogito. Kartezjuszowi wystarczy, że współzależność obu jest przekonująca i niepodważalna. Szuka on tylko absolutnej pewności, a prawda, która w tej pewności jest pewna, może być jakakolwiek bądź. Dla Kartezjusza bycie Ja, którego dotyczy cogito ergo sum, nie jest godne pytania, nie staje się problemem. Wystarcza mu niepowattpiewalna obecność Ja w „myślę".

W tym miejscu warto uzupełnić wywód Heideggera, przypominając jego późniejsze konstatacje: Kartezjańska pewność (Gewißheit) to swoista kontynuacja i sekularyzacja chrześcijańskiej wiary, którą to wiarę Heidegger nazywa pewnością zbawczą (Heilsgewißßheit) (N II, s. 425-427). Tym, co absolutne, nie jest już doskonały byt, lecz to, co jest matematycznie absolutne, tzn. cokolwiek spełniającego metodyczny warunek pewności (GA 23, s. 142). Gdy w wieku wojen religijnych dawna wiara w Boga przestała dawać oparcie udręczonemu człowiekowi, a zarazem

29 Ibidem, s. 96.

30 Ibidem, s. 98. 
doszło do spektakularnych sukcesów nauk ścisłych, owa przemiana wydaje się czymś naturalnym, przynajmniej gdy się patrzy z historycznego dystansu.

Kartezjański podmiot ma wprawdzie odniesienie do czasu jako substancja skończona i stworzona - kontynuuje Heidegger w Geschichte - jednak francuski filozof w ogóle nie rozważa czasowych wymiarów egzystencji. Rozpościera się ona po prostu między momentem narodzin i śmierci. Tymczasem, egzystując, jestestwo zawsze, w każdej chwili swojego życia, rodzi się i umiera na nowo; odnosi się do swojej śmierci i narodzin, niesie je w sobie. Pewność śmierci jest większa i zupełnie inna niż pewność cogito ergo sum i każdego twierdzenia matematycznego (GA 23, s. 140).

Kartezjańska pewność wywodzi się z matematyki, tzn. Descartes bierze stamtąd najogólniej pojętą metodę - Heidegger nazywa ją ideą matematyczną - na którą składa się intuicja i dedukcja. Ta pierwsza to jasne i wyraźne ujęcie idei i oczywistość sądu składającego się z owych idei. Dedukcja, czyli wnioskowanie logiczne, zawiera w sobie pewien ruch czy kolejność, którego intuicja, jako bezpośrednie uchwycenie oczywistej prawdy, jest pozbawiona (GA 23, s. 142). Idea matematyczna kieruje poszukiwaniem aksjomatu metafizyki, ale też determinuje interpretację przyrody. Dopiero teraz wkracza na scenę matematyka jako konkretna nauka pozytywna. Heidegger stawia zarzut: Descartes nie pyta o ukonstytuowanie bycia bytu wewnątrzświatowego, lecz interpretuje bycie przyrody tak, by matematyzacja stała się możliwa, tzn. liczy się tylko rozciągłość rzeczy cielesnej. Prawda „Ja myślę" ma być wieczna i wieczna ma być prawda przyrody. W przeciwieństwie do tego Heideggerowskie Dasein jest dziejowe. Interpretacja cielesności również uzależniona jest od każdorazowego dziejowego projektu świata życia codziennego (GA 23, s. 143, 229).

Wykład Geschichte der Philosophie von Thomas von Aquin bis Kant obejmuje także obszerną analizę Etyki Spinozy. Destrukcja systemu Spinozy została tu przeprowadzona drobiazgowo, jak nigdzie indziej. Heidegger podkreśla znów bliskie związki metafizyki Spinozy ze średniowieczną scholastyką. Zaznacza, że oddziałała ona na autora Etyki bezpośrednio, a nie dopiero przez Kartezjusza - gdy 22-letni Spinoza po śmierci ojca zaczął się uczyć łaciny i greki. Podjął także studia teologiczne nad wpływową wówczas hiszpańską arystotelesowską scholastyką (GA 23, s. 145).

Podług Heideggera, u Spinozy grecka idea bycia - substancjalność substancji uzyskuje ekstremalne rozwinięcie. Pomyślana jest radykalnie i do końca. Struktura całego bytu i jej możliwości zaprojektowane są zgodnie z nią. Spinoza jednoczy kilka ujęć bytu: 1. podział na Boga, który jest przyczyną samego siebie, i byt stworzony; 2. podział na substancję i przypadłość; 3. podział na byt pojęty sam przez się i pojęty przez od- 
niesienie do innego bytu ${ }^{31}$. Zakłada to identyczność bycia pomyślanym (pkt 3) oraz bycia rzeczywistym, tzn. właściwej obecności (pkt 1 i 2). Bóg Spinozy to substancja nieskończona, jedyny byt, w którym i przez który wszystko jest (GA 23, s. 148-150, 152-153) 32. Spinoza wyraźnie nawiązuje także do definicji Kartezjusza: substancja jest rzecza, która żadnej innej nie potrzebuje do swego istnienia. Taką substancją w ścisłym sensie jest Bóg. Inne rzeczy istnieją za sprawą udziału Boga ${ }^{33}$. Mimo to Kartezjusz przyjmuje trzy rodzaje substancji: nieskończoną (Boga) oraz dwie skończone (myślącą i rozciągłą). Spinoza konsekwentnie poprzestaje na jednej substancji (GA 23, s. 148, 150) ${ }^{34}$.

Jako że w Etyce stosuje się Kartezjańską metodę intuicji i dedukcji, najważniejsze jest - zaznacza Heidegger - przedyskutowanie podstawowych definicji i aksjomatów określających pojęcie substancji. Zasadnicze aspekty bycia człowieka wynikają z bycia bóstwa-substancji. Bycie człowieka ufundowane jest na najważniejszym, ,zbawczym” stosunku do źródłowego bytu - to amor intellectualis Dei, umiłowanie rozumowe bóstwa. Heideggerowska destrukcja systemu Spinozy sprowadza się właśnie do wykazania, że koncepcja ludzkiej egzystencji została tu dopasowana do antycznej idei substancjalności substancji i rozpuszczona w czystej obecności wiecznego Boga (GA 23, s. 165).

Zgodnie z powyższym należy zwrócić szczególną uwagę na ontologiczne pojęcia podstawowe, wymienione na początku I części Etyki. Pierwszym jest pojęcie przyczyny siebie samej (causa sui). Jest ona tym, czego istota zawiera w sobie istnienie, czyli tym, czego natura pojęta być może tylko jako istniejąca. Pojęcie istoty zawierającej w sobie istnienie nie wymaga odniesienia do pojęcia przyczyny. Wystarczy powiedzieć o czystej obecności. Postępowanie Spinozy ujawnia jego zależność od arystotelesowskiej scholastyki. W idei bycia pomyślane jest wytwarzanie. Bóstwo Spinozy, uosabiające ideę bycia w sensie absolutnej obecności, pomyślane zostało negatywnie jako to, co wytwarzania nie potrzebuje (GA 23, s. 150, 153). Należy jednak przypomnieć, że Spinoza

31 Jest to zjednoczenie podziałów na: 1 . ens a se-ab alio; 2. ens per se-per accidens; 3. ens in se-ad aliud (zob. GA 23, s. 216).

32 Późny Heidegger w związku z tym zauważa: „podstawowe pojęcia metafizyczne średniowiecznej scholastyki po prostu zostały [przez Spinozę] zdumiewająco bezkrytycznie wbudowane w system” i nazywa on ów system „niepowtarzalnie jednostronnym" (RS, s. 56).

33 R. Descartes, Zasady filozofii, przeł. I. Dąbska, Wydawnictwo Antyk, Kęty 2001, cz. 1 , pkt 51, s. 43-44.

34 Tomasz z Akwinu dopuszcza stwierdzenie, że Bóg jest substancja, ale byłaby to substancja bez przypadłości oraz bez rodzaju i różnicy gatunkowej (Suma filozoficzna, cz. 1, rozdz. 23 i 24). Odróżnia także ogólne sposoby bycia, wyrażone przez pojęcia transcendentalne, od szczególnych sposobów bycia, wyrażonych przez pojęcie substancji i przypadłości, tzn. przypadłość istnieje mniej niż byt jednostkowy, będący jej podłożem (Kwestie dyskutowane o prawdzie, kw. 1, art. 1). 
dystansuje się od wszelkiej teleologii i antropomorfizmu. Bóstwo jako przyczyna (niem. Ursache) zinterpretowane jest czysto ontologicznie jako prarzecz (niem. Ur-sache). Bóstwo w żadnym razie nie produkuje samego siebie i rzeczywistości (por. GA 23, s. 152). Spinoza, inaczej niż Tomasz z Akwinu, nie wychodzi od skutków boskiego działania, by wznieść się następnie do samego Boga, lecz rozpoczyna od bóstwa, stosując konsekwentnie procedurę dedukcyjną (GA 23, s. 152) ${ }^{35}$. Ma u niego miejsce równoległość porządku bytu i porządku poznania. Rzeczywistość formalna rzeczy schodzi się z rzeczywistością obiektywną idei ${ }^{36}$. Szereg przyczyn sprawczych po stronie rozciągłości ma swój odpowiednik w szeregu dedukcyjnym po stronie myślenia (GA 23, s. 151-152) czyli bóstwo jest zarazem pierwszą przyczyną sprawczą (nie przyczyną celową) oraz pierwszą racją logiczną.

Definicja pierwsza, objaśniająca pojęcie przyczyny samej siebie, oraz definicja druga, objaśniająca pojęcie rzeczy skończonej w swoim rodzaju, to u Spinozy czysto formalnie pomyślany podział na byt niestworzony i stworzony - zapożyczenie od scholastyki i Kartezjusza (GA 23, s. 153). Następne trzy definicje: substancji, atrybutu i modusu mają umożliwić projekcję antycznego pojęcia substancji na pojęcie bóstwa. Atrybut, czyli to, co rozum poznaje z substancji jako stanowiące jej istotę, oznacza cechę konstytutywną, cechę wchodzącą w skład definicji (niezależnie od tego, czy taka definicja jest dla człowieka możliwa; w istocie nie jest ona dla nas możliwa, gdyż jesteśmy w stanie poznać tylko dwa atrybuty bóstwa). Modus, czyli pobudzenie substancji, jest jej przypadłością (GA 23, s. 154). Spinoza po prostu przejmuje te kategorie z arystotelesowskiej scholastyki, nie pytając o ich pochodzenie. Heidegger tutaj, tak jak w innych pismach, wywodzi je z myślenia w sensie wypowiadania sądów, ze struktury zdania oznajmującego (GA 23, s. 155) ${ }^{37}$. Przez atrybuty substancja udziela się pojmowaniu. Samo istnienie substancji na nas nie działa. Bycie jest tym, co negatywne. Trudność wszelkiej ontologii wynika stąd, że pozostaje ona przy tym, co negatywne - w interpretacji Kanta: bycie nie jest predykatem realnym (ontycznym) (GA 23, s. 153-154).

Mogłoby stąd wynikać, że atrybuty nie należą do substancji jako takiej, są tylko subiektywnymi sposobami jej pojmowania przez podmiot. Przeczy temu jednak wyraźne stwierdzenie Spinozy: „Nie jest więc nam

35 B. Spinoza, Etyka w porządku geometrycznym dowiedziona, w: idem, Traktaty, przeł. I. Halpern-Myślicki, Wydawnictwo Antyk, Kęty 2000, cz. 2, tw. 10, przypisek, s. 505; zob. też wcześniej.

36 Zob. wcześniej.

37 ,Czy istotowa budowa prawdy i zdania jest dostosowana do budowy rzeczy? A może jest na odwrót, istotowa budowa rzeczy jako nośnika własności jest wyłożona zgodnie $\mathrm{z}$ budową zdania jako jedności »podmiotu« $\mathrm{i}$ »orzeczenia«? Czy człowiek odczytał budowę zdania z budowy rzeczy, czy może włożył budowę zdania w rzeczy?" (PR, s. 46; zob. też Źródło dzieła sztuki, DL, s. 12). 
dane poza rozumem nic, przez co rzeczy różnić by się mogły między soba, prócz substancji lub, co to samo znaczy, ich atrybutów oraz ich po-

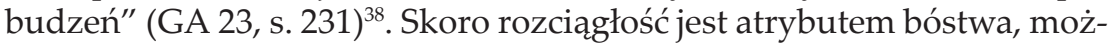
na pytać, czy bóstwo jest rozciągłe, a nawet, czy jest ono materialne ${ }^{39}$. Spinoza odpowiada: do substancjalności jedynej substancji należy tylko istota rozciągłości, a ta jest niepodzielna i niematerialna, tak jak istota wody jest niepodzielna i niematerialna, w przeciwieństwie do wody poznawanej zmysłowo. Rozciągłość pojmowana przez wyobraźnię jest skończona, podzielna i złożona z części, rozum zaś pojmuje niezmienną istotę rozciągłości (GA 23, s. 156-157)

Rozstrzygające twierdzenia odnośnie do hipotetycznej rozciągłości i materialności bóstwa znajdujemy w liście Spinozy do Lodewijka Meyera z 20.04.1663 r. i jego liście do Jariga Jellesa z 2.06.1674 r. Heidegger ich jednak w swym wykładzie nie cytuje. Miara, czas i liczba są tylko pomocniczymi narzędziami wyobraźni, nie są więc dane poza rozumem, mają charakter subiektywny. Modusy substancji, tak jak atrybuty, istnieją obiektywnie, ujmuje je myślenie, które u Spinozy jest oczywiście wyższą formą poznania niż poznanie zmysłowe (mniemanie) i wyobraźnia (zob. GA 23, s. 151, przypis) ${ }^{41}$. Materia rozważana jako coś nieokreślonego nie ma żadnego kształtu. Kształt jest ograniczeniem, a ograniczenie zaprzeczeniem (omnis determinatio est negatio), zatem kształt jest zaprzeczeniem materii rozważanej ze względu na jej byt, tzn. istoty materiii ${ }^{42}$. To, co podlega określeniu - tłumaczy zamysł Spinozy Heidegger - musi z góry i absolutnie istnieć przed wszelkim zaprzeczeniem, przed wszelką skończonością (GA 23, s. 157).

Heidegger rozważa również Spinozjańską definicję wieczności. Jak już wiadomo, istnienie zawiera się $\mathrm{w}$ istocie bóstwa ${ }^{43}$. Wieczność jest właśnie istnieniem wynikającym z istoty substancji. Nie może być objaśniona przez czas lub trwanie (rozumiane jako bezkresny upływ czasu) (GA 23, s. 156). Wiemy już, dlaczego tak jest: czas, liczba, miara to tylko narzędzia wyobraźni, związane z ludzkim sposobem doświadcza-

38 B. Spinoza, Etyka, cz. 1, tw. 4, s. 467 (słowo „istota" zamieniłam na „,substancja”, słowo „przymiot” na „atrybut”).

39 Spinoza nie rozgranicza wyraźnie rozciągłości i materialności. Nie zgadza się z poglądem Kartezjusza, że rozmaitość ciał materialnych można wyprowadzić z rozciągłości, zakładając ruch wzniecony w niej przez Boga, ale wielość ciał materialnych chce wyjaśniać za pomocą ograniczeń atrybutu rozciągłości. Zauważa również bezwładność materii, której z samej rozciągłości wywieść niepodobna (Listy mężów uczonych do Benedykta de Spinozy oraz odpowiedzi autora wielce pomocne dla wyjaśnienia jego dzieł, przeł. L. Kołakowski, PWN, Warszawa 1961, listy 81, 82, 83, s. 339-341; zob. też list 73, s. 316).

40 B. Spinoza, Etyka, cz. 1, tw. 15, przypisek, s. 477.

41 Idem, Listy mężów uczonych do Benedykta de Spinozy, list 12, s. 54.

42 Ibidem, list 50, s. 232.

${ }^{43}$ Zob. wcześniej; „,istnienie Boga jest samą jego istotą” (ibidem). 
nia rzeczywistości. We wskazanym liście do Meyera Spinoza definiuje wieczność jako nieskończone korzystanie $\mathrm{z}$ istnienia, bytowania ${ }^{44}$. Konsekwentnie atrybuty korzystałyby z istnienia w sposób nieskończony, ale ograniczony, zaś modusy w sposób skończony.

W kolejnych częściach Etyki Heidegger uwydatnia wątki osobliwie anonsujące metafizykę Leibniza. W części II okazuje się, że wszystek byt jest ożywiony bądź uduchowiony (zob. GA 23, s. 158-159). Paralelizm myślenia i rozciągłości zostaje tu zachwiany. Obowiązuje zasada, że przyczyną idei nie jest nigdy rzecz w niej pomyślana, a także ciała nie są określone przez idee, jednak „Porządek i związek idei jest taki sam, jak porządek i związek rzeczy"45. Tymczasem każdej idei odpowiada idea idei, tzn. idea o umyśle (świadomość, samowiedza); „Albowiem skoro ktoś wie coś, to przez to samo wie, że to wie i zarazem wie o tym, iż wie i tak do nieskończoności” ${ }^{46}$. „Myślę" oznacza zawsze „myślę moje myślenie". Wszystkie osobniki, nie tylko ludzie, są uduchowione (animata), chociaż w różnym stopniu ${ }^{47}$, czyli wszystkie osobniki posiadają świadomość w różnym natężeniu. Aż się prosi, by wspomnieć tutaj o konstrukcji reditio in se ipsum ${ }^{48}$, czego jednak Heidegger nie czyni.

Na wstępie części III Spinoza zaznacza, że afekty należy badać naukowo, tak jak linie, płaszczyzny i ciała materialne. Afekty, jak wszystko inne, można wywieść z pojęcia substancji. Nie są one jakimś państwem w państwie i nie świadczą o jakimś zasadniczym skażeniu istoty ludzkiej. Afekt to pobudzenie ciała, a zarazem idea tego pobudzenia ${ }^{49}$. Ma tu znowu miejsce równoległość myślenia i rozciągłości. Ontologiczny problem afektów sprowadza się - zauważa Heidegger - do wyjaśnienia, jak to możliwe, że jakiś byt znajduje się, jest położony (befindet sich) tak lub inaczej i w tym znajdowaniu się jest tak a tak nastrojony (gestimmt) (GA 23, s. 160-161). W Byciu i czasie pojęcie nastroju wyraża także słowo położenie (Befindlichkeit).

Heidegger chwali Spinozę za przedzieranie się do problemu afektów drogą badania ontologicznego, a nie metodą „złej empirii, która wzywa na pomoc tzw. fakty, które nigdy niczego nie wyjaśniaja, ale same wcześniej wymagają określenia [swej] istoty" (GA 23, s. 161). Ontologia afektów ma tu konstrukcję bardzo przejrzystą (GA 23, s. 160-161). Wszystkie afekty wyprowadzone zostały z trzech podstawowych: jednego afektu czynnego - pożądania i dwóch afektów biernych - radości i smutku.

44 Ibidem, list 12, s. 52. Chodzi tu o nieskończoność aktualną, którą można pojąć tylko umysłem (zob. ibidem, s. 55).

45 B. Spinoza, Etyka, cz. 2, tw. 7, s. 502.

46 Ibidem, cz. 2, tw. 21, przypisek, s. 516.

47 Ibidem, cz. 2, tw. 13, przypisek, s. 507.

48 Zob. wcześniej.

49 B. Spinoza, Etyka, cz. 3, def. 3, s. 539. 
Podstawowy afekt czynny - dążność (conatus) ma trzy odmiany: należąca do samego umysłu jest wolą (voluntas), należąca do umysłu i ciała zarazem, bez towarzyszącej temu świadomości, jest popędem (appetitus), należąca do umysłu i ciała wraz ze świadomością jest pożądaniem (cupiditas) $^{50}$.

Podobnie jak u Leibniza, wszystkie rzeczy poszczególne, tzn. wszystkie modusy bóstwa, cechuje dążenie, a konkretnie dążenie do zachowania swego bytu ${ }^{51}$. Jedynie substancja jako taka, w sensie natura naturans, nie dąży do niczego, jest wolna (bo nic jej nie przymusza do działania), ale nie posiada woli ${ }^{52}$. Również u Leibniza Bóg, będący monadą monad, nie zawiera w sobie żadnego braku, który powinien zostać zniwelowany drogą dążenia do ideału. W obu przypadkach bóstwo ma niejako swój byt na własność, jest już gotowe, zrealizowane. Na to podobieństwo zwrócił już uwagę Gotthold E. Lessing (zob. GA 23, s. 187-188).

W części IV Etyki dobro i zło człowieka, tzn. podług Spinozy jego większa lub mniejsza doskonałość, zostały uzależnione od przybliżania się do wzoru natury ludzkiej, jaki stawiamy przed sobą, bądź oddalania się od niego ${ }^{53}$. Cnotę Spinoza definiuje jako dążenie człowieka do zachowania swego bytu. Jest ona aktywną mocą człowieka, jego własną istotą w działaniu. Cnota wymaga kierowania się w życiu rozumem. Jest ona przeciwieństwem pozostawania $w$ niewoli afektów biernych, o podłożu cielesnym (GA 23, s. 162-163) ${ }^{54}$. Znowu należy zwrócić uwagę na podobieństwo kondycji ludzkiej w ujęciu Spinozy do pierwotnej mocy czynnej (vis primitiva activa) Leibnizjańskiej monady. Monada pragnie jednak nie tyle zachowania własnej istoty, ile jej urzeczywistnienia, przy czym jest ono procesem niemal mechanicznym, zapoczątkowanym przez akt stwórczy Boga. W obu przypadkach nasuwają się skojarzenia z Heideggerowską egzystencją właściwą. Niektóre wyjaśnienia Spinozy wskazują wszakże na coś bardziej prozaicznego: cnota to po prostu dążenie do swego pożytku bądź życie zgodne z rozumem, bo człowiek jest istotą rozumną ${ }^{55}$.

W części V Etyki najdoskonalszy, docelowy stan człowieka zostaje określony jako umiłowanie rozumowe bóstwa (amor intellectualis Dei). Wyjaśnienie tej tezy wymaga przyjęcia kilku założeń (zob. GA 23, s. 162-163). Po pierwsze, poznanie jako takie nie może wyprzeć żadne-

50 Ibidem, cz. 3, tw. 9, przypisek, s. 545-546; tw. 11, przypisek, s. 546-547.

51 Ibidem, cz. 3, tw. 6 i 7.

52 Zob. ibidem, cz. 1, tw. 17, przypisek, s. 479-480; tw. 31, s. 487.

53 Ibidem, s. 590.

54 Ibidem, cz. 4, tw. 20, s. 601; tw. 24, s. 603.

55 Zob. ibidem, cz. 4, tw. 20, s. 601; tw. 35, dodatek 1, s. 608. W drugim przypadku argumentacja Spinozy jest taka sama, jak u starożytnych stoików - dla człowieka życie zgodne $\mathrm{z}$ naturą to życie zgodne $\mathrm{z}$ rozumem. 
go afektu. Afekt może zostać wyparty jedynie przez afekt silniejszy ${ }^{56}$. Po drugie, najwyższym szczęściem człowieka jest doskonałe poznanie bóstwa, czyli poznanie siebie samego i wszystkich rzeczy dostępnych dla ludzkiego rozumu. To szczęście może być wspólne wszystkim ludziom $^{57}$. Po trzecie, (przytaczam charakterystykę Heideggera) „im jaśniej poznajemy afekt, tym bardziej nasze zachowanie jest czystym działaniem, a czyste poznające odniesienie do tego, co poznane, jest poznaniem Boga" (GA 23, s. 163) ${ }^{58}$. W konsekwencji - największa radość płynąca z poznania (także ze zrozumienia swoich afektów) wypiera wszystkie pozostałe afekty, daje zaspokojenie ludzkiego umysłu i pozwala zjednoczyć się ze wszystkimi postępującymi w ten sposób ludźmi. Radość w powiązaniu z ideą przyczyny zewnętrznej jest miłością ${ }^{59}$ - w tym wypadku umiłowaniem rozumowym bóstwa. Zauważamy tu przejście od wnioskowania i pojmowania do radości i spoczywania miłującego w Bogu (zob. GA 23, s. 165, przyp.). Podobne momenty wyróżnił Tomasz z Akwinu, charakteryzując najwyższy stan człowieka, niemożliwy do osiągnięcia w sposób trwały w życiu doczesnym - wizję uszczęśliwiającą ${ }^{60}$.

Nieco miejsca Heidegger poświęca zagadnieniu nieśmiertelności ludzkiego umysłu w systemie Spinozy (zob. GA 23, s. 164). Wydawałoby się, że jest ona wykluczona, gdyż „umysł wyraża rzeczywiste istnienie swego ciała i pojmuje pobudzenia ciała jako rzeczywiste tylko podczas trwania ciała"61. Wszelako bóstwo jest przyczyną nie tylko istnienia każdego ludzkiego ciała, ale i jego istoty. Owa istota koniecznie dana jest $\mathrm{w}$ bóstwie, $\mathrm{tzn}$. wynika $\mathrm{z}$ istoty bóstwa $\mathrm{z}$ wieczną koniecznością. Idea ludzkiego ciała istnieje $\mathrm{w}$ bóstwie pod postacią wieczności (sub specie aeternitatis $)^{62}$. Jak już wiadomo, wieczność nie może być określona za pomocą czasu, gdyż ów jest tylko pomocniczym narzędziem ludzkiej wyobraźni. Heidegger objaśnia: „Sub specie aeternitatis musi być więc pojęte ściśle ontologicznie, przez wzgląd na wieczne »co«. Także po zniszczeniu ciała pozostaje coś, co jest wieczne" (GA 23, s. 164).

Heideggerowska krytyka stanowiska Spinozy wygląda następująco: wprawdzie celem Spinozy jest określenie bycia i istoty człowieka, ale faktycznie zostają one "rozpuszczone” w czystej obecności wiecznego bytu (warto uzupełnić, że sprzyja temu przyjęcie przez Spinozę postulatu Kartezjusza, by „naukowa” etyka stała się zwieńczeniem metafizyki).

\footnotetext{
56 Ibidem, cz. 4, tw. 7, s. 594; tw. 14, s. 598.

5 Ibidem, cz. 4, tw. 36, s. 608-609; przydatek, s. 632.

8 Ibidem, cz. 5, tw. 3, s. 641; tw. 15, s. 647.

9 Ibidem, cz. 3, tw. 13, przypisek, s. 548.

Zob. wcześniej.

61 B. Spinoza, Etyka cz. 5, tw. 21, s. 650.

62 Ibidem, cz. 5, tw. 22, s. 651.
} 
Spinoza nie projektuje, jak twierdzą niektórzy, swego ideału osobowości na absolut, ale odwrotnie - dopasowuje ujęcie ludzkiej egzystencji do antycznej idei substancjalności substancji. Specyficzna pojedynczość człowieka tu przepada i nie może stać się problemem filozoficznym (zob. GA 23, s. 165-166) ${ }^{63}$.

W drugiej części niniejszego artykułu, w kolejnym numerze „Ruchu Filozoficznego", prześledzimy interpretację filozofii Leibniza i idealizmu niemieckiego.

\section{Wykaz skrótów cyłowanych dzieł Martina Heideggera}

BC Bycie i czas, przeł B. Baran, Wydawnictwo Naukowe PWN, Warszawa 1994.

BMM Budować, mieszkać, myśleć, przeł. K. Michalski, K. Pomian, M. J. Siemek, J. Tischner, K. Wolicki, SW Czytelnik, Warszawa 1977.

DL Drogi lasu, przeł. J. Gierasimiuk, R. Marszałek, J. Mizera, J. Sidorek, K. Wolicki, Fundacja Aletheia, Warszawa 1997.

GA xx Gesamtausgabe, t. 20, Vittorio Klostermann, Frankfurt am Main.

GA 1 Frühe Schriften (1912-1916), Vittorio Klostermann, Frankfurt am Main 1978.

GA 23 Geschichte der Philosophie von Thomas von Aquin bis Kant, Vittorio Klostermann,Frankfurt am Main 2006.

GA 26 Metaphysische Anfangsgründe der Logik im Ausgang von Leibniz, Vittorio Klostermann, Frankfurt am Main 1990.

GA 49 Die Metaphysik des deutschen Idealismus. Zur erneuten Auslegung von Schelling (1941), Vittorio Klostermann, Frankfurt am Main 1991.

N II Nietzsche, t. 2, przeł. A. Gniazdowski, P. Graczyk, W. Rymkiewicz, M. Werner, C. Wodziński, Wydawnictwo Naukowe PWN, Warszawa 1999.

PPF Podstawowe problemy fenomenologii, przeł. B. Baran, Fundacja Aletheia, Warszawa 2009.

PR Pytanie o rzecz, przeł. J. Mizera, Wydawnictwo KR, Warszawa 2001.

RS Rozprawa Schellinga o istocie ludzkiej wolności [1809], przeł. R. Marszałek, Wydawnictwo KR, Warszawa 2004.

${ }_{63}$ Moja uwaga: jednak pojedynczość człowieka zostaje tu w jakiejś mierze ocalona przez jednostkowość ludzkiego ciała, któremu odpowiada konkretna wieczna idea ludzkiego umysłu. Naszym obowiązkiem, według Spinozy, jest zachowanie tej idealnej postaci własnej osobowości. 


\section{Heidegger's destruction of metaphysics: mediaeval and modern philosophy. Part I}

\section{Keywords}

St Thomas Aquinas, Descartes, Spinoza, transcendentalia, reditio in se ipsum, proofs of God's existence, time, imagination, intellect, appetence, actual infinity, infinite and finite substance

The article is focused on thorough analysis and "destruction" of St Thomas's Aquinas, Descartes's and Spinoza's philosophy undertaken by M. Heidegger in the years 1926-27 (Gesamtausgabe Vol. 23). As to St Thomas's metaphysics Heidegger follows the explanation of mutual connections of transcendental notions: ens, res, unum, aliquid, veritas, bonum. He fixes his attention on the last two ones. The notion of veritas gives opportunity to concern St Thomas's theory of knowledge. The real ontology of Aquinas is hidden - in Heidegger's opinion - in his "proofs" of God's existence. The metaphysics of Cartesius and Spinoza (detailed explanation of the Meditations and the Ethics) is presented by Heidegger such as to prove their dependence upon the medieval scholasticism. Exposition of Cartesian philosophy in Gesamtausgabe Vol. 23 is valuable complement of the Cartesian concept of world reconstructed in the Sein und Zeit. Descartes, such as Spinoza, is not interested in the special way of Being and the specific temporality of the human Dasein. Cartesius chiefly tends to find the absolutely certain axiom of metaphysics. Spinoza "dissolves" human Dasein in the eternal substance conceived radically, to the end, in Aristotelian-scholastic way. 